
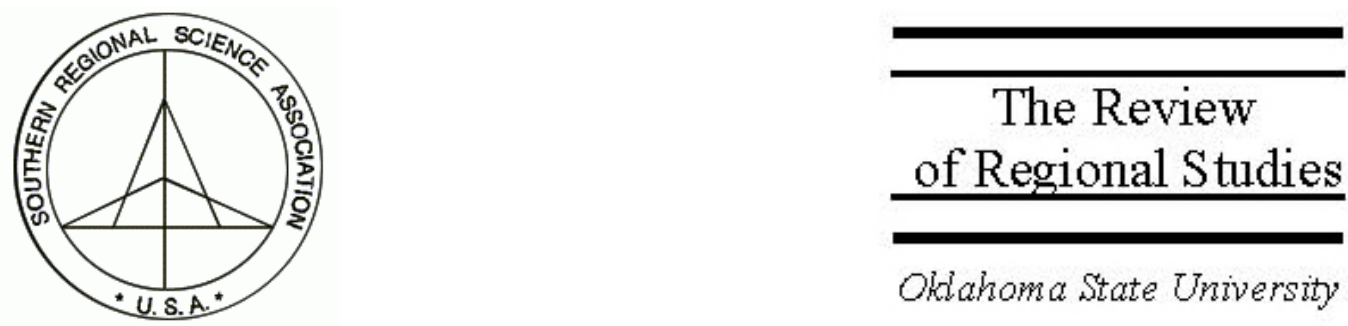

\title{
The Impact of Wal-Mart on Income and Unemployment Differentials in Alabama
}

\author{
Stanley R. Keil \\ Department of Economics, Ball State University, Muncie, Indiana, 47306, \\ e-mail: skeil@bsu.edu \\ Lee C. Spector \\ Department of Economics, Ball State University, Muncie, Indiana, 47306, \\ e-mail:001cspector@bsu.edu
}

\begin{abstract}
Using Alabama county data from 1980 and 1990 censuses and store opening dates, this paper presents an econometric study of the impact of the presence of Wal-Mart on black-white income and unemployment differentials. It is posited that Wal-Mart changes the competitive nature of the labor market in a way that is beneficial to blacks. After establishing a list of demographic and economic variables that affect unemployment and income, the impact of a Wal-Mart is tested by using a dummy variable and a cumulative-years variable. Wal-Mart is found to have substantially lowered the relative unemployment rates of blacks in those counties where it is present, but to have had only a limited impact on relative incomes after the influences of other social-economic variables are taken into account.
\end{abstract}

Keywords: Wal-Mart; Labor market; Labor mobility; Regional economics; Retail trade; Wage differentials

JEL classification: J15; J61; R11

Data gathering assistance was provided by Gregory Martz. Other than the opening dates for the Wal-Mart stores in Alabama, all data are drawn from the 1980 and 1990 Census. We are prepared to share all of the data used in this paper. All statistical analysis was done using EVIEWS or Microsoft EXCEL 2002, and the data are available from the authors in either format. 


\section{INTRODUCTION}

Income and unemployment differentials between whites and blacks (or males and females) have been the subject of a substantial amount of literature. The wage differential and, similarly, the unemployment differential literature posits three reasons for these differentials: human capital variation, discrimination, or different utility functions. Because isolating these effects is very difficult, this paper does not focus on why any wage or unemployment differentials occur. ${ }^{1}$ Rather, it attempts to answer a more general question. Following Holzer's (1991) work on the relationship of demand shifts on employment, this paper tests the hypothesis that the introduction of a Wal-Mart into a county, by increasing the demand for labor, reduces income or unemployment differentials between blacks and whites. Establishing a new Wal-Mart increases the demand for labor primarily at the low end of the human capital distribution. If blacks are substantially over-represented at the low end, the effect should be a reduction of the unemployment rate of blacks relative to whites. And, depending on the salaries obtained by these newly employed members of the labor force relative to previously employed members, Wal-Mart might have an impact on income differentials as well. This paper, then, adds to the literature that examines the role of competition in reducing income and unemployment differentials between blacks and whites. However, while most of these studies focus on industry-wide effects, we examine the impact of one large firm entering a particular geographic area. Specifically, we test the hypothesis that the existence of a Wal-Mart in an Alabama county changed the unemployment and income differentials between blacks and whites in that county during the decade of the 1980s.

While the impact of competition on income and unemployment differentials in particular geographic areas has been studied, most of this research involves the impact of relaxing trade restrictions. ${ }^{2}$ There is also the possibility that Wal-Mart has reduced both labor market discrimination and customer discrimination (by raising the premium those customers who discriminate pay for their preferences), both of which could reduce unemployment differentials and income differentials. ${ }^{3}$ Testing these discrimination hypotheses is beyond the scope of the data available for this paper. However, if these forms of discrimination exist and Wal-Mart reduces them, we should find Wal-Mart to

\footnotetext{
${ }^{1}$ For example, two teachers with degrees in the same subject might have different wages or employment opportunities due to location preferences. Likewise, two individuals might have different human capital due to past discrimination.

${ }^{2}$ For example, Jones and Walsh (1991) and Hazarika and Otero (2002) find that the reduction of trade restrictions lowers employment and wage differentials. On the other hand, Berik, Rodgers, and Zveglich (2002) find foreign trade leads to an increase in the wage differentials between men and women.

${ }^{3}$ Becker (1957), Alchian and Kessel (1962), and others have cogently argued that in a competitive product market, employer and employee discrimination eventually disappear. Until Kahn's (1991) paper, it was also the consensus that customer discrimination could not cause permanent wage differentials (see Cain, 1986). Also see Heywood (1987); Medoff (1980); Hassel and Palmer (1978); Johnson (1978); and Hellerstein, Neumark, and Troske (2002). The literature on discrimination is, of course, huge.
} 
have a stronger impact on both unemployment and income differentials. Finally, the new employment opportunities provided by Wal-Mart are likely to change the expected rates of return for workers in the retail sector, thereby leading more individuals to find it utility maximizing to search for employment in that sector.

\section{WHY WAL-MART?}

Wal-Mart was chosen for three reasons. First, it is a large enough employer to have an impact on a given area. ${ }^{4}$ Second, since it is a national concern, its business practices reflect a national policy of equal opportunity hiring practices rather than the historical practices of any given area. Third, Wal-Mart hires mostly lower skilled workers. Many researchers have found that lower skilled workers are less apt to migrate or commute to areas where demand has increased. However, most increases in demand are not for lower skilled workers. $^{5}$ Thus, while we hypothesize that a new Wal-Mart results in a net increase in employment in local low-skill labor markets, we recognize that what happens to local income and unemployment rates depends, in part, on how many of the new jobs go to previously unemployed local workers, to job switchers, to local persons who were not in the labor force, and to migrants and commuters from other counties. We will comment on this where we can, but we do not have data of sufficient detail to parse new job takers into these separate categories.

Recently, there has been substantial controversy concerning the employment impact of the entrance of a Wal-Mart into a particular geographic area. Newspaper stories often appear when a new Wal-Mart opens voicing concerns that it will destroy jobs in the retail sector and put smaller retailers (usually downtown or neighborhood retail centers) out of business. ${ }^{6}$ The geographic impact of Wal-Mart is less clear. Some downtown businesses in cities where Wal-Marts have located have benefited from the greater draw of customers. Others have been devastated by the overwhelming new competition for their customers' dollars. In a study of the impact of 14 Wal-Marts in Iowa, Kenneth Stone (1995) found positive impacts in towns where Wal-Mart had located. However, there was clearly a negative impact on other towns in the surrounding area; towns within a 20mile radius of the Wal-Mart stores saw total retail sales drop an average of 25 percent after five years. Wal-Mart attracts customers from a substantial distance. Businesses that sell goods or services not sold by Wal-Mart tend to experience higher sales because of the spillover effect. But some of these sales come at the expense of smaller town retailers. The stores that perform the best are those selling complementary products that are willing to move from downtown to strip malls near a Wal-Mart store. However, businesses that sell the same goods as Wal-Mart tend to experience reductions in sales after Wal-Mart opens. This loss may be as much as 10 percent within three years of the

\footnotetext{
${ }^{4}$ A recent article (Yencer, 2004) estimated that a super Wal-Mart employs 450 people.

${ }^{5}$ See Bound and Holzer (2000).

${ }^{6}$ See Welles (1993) for a discussion of the total impact of Wal-Mart on traditional downtown retail jobs.
} 
opening of a Wal-Mart. While our research speaks to these concerns, it does so only in an indirect way.

\section{WHY ALABAMA?}

Alabama was chosen for several reasons. In 1980, Alabama had a substantial black population with a mean income less than 68 percent of white mean income and an unemployment rate 2.39 times higher than that of whites. To the extent that these differences are attributable to the demand side of the labor market, there was substantial room for Wal-Mart to have an impact. Opening dates for each of the Wal-Mart stores in Alabama show that only one store was open before 1980. By 1990, 44 counties had one or more Wal-Marts. There were sufficient counties in 1990 without a Wal-Mart to form a control group for "with and without" measurements. We also have the opening dates for the Wal-Mart stores in each county, which allowed testing of the cumulative impact of WalMart from opening date through the beginning of 1990. We dropped one county (Walker) that had a Wal-Mart open in the 1970s. In the remaining counties, either one or more Wal-Marts opened during the 1980s or there was no Wal-Mart present as of January 1, 1990. We have 1980 and 1990 census data for Alabama's 67 counties for most of the basic socioeconomic variables outlined below in the description of the base model. Data are missing for some variables in small counties in both census years due, according to the U.S. Census Bureau, to inadequate samples or samples with substantial sampling errors.

\section{EMPIRICAL ANALYSIS}

\subsection{Summary Statistics}

Our analysis focuses on changes in relative unemployment rates and incomes for blacks compared to whites. Absolute unemployment rates were lower in 1990 than in 1980 for both blacks (13.2 percent versus 13.4 percent) and whites (5.0 percent versus 5.3 percent). Table 1 shows the ratio of the black unemployment rate to the white unemployment rate for Alabama and the U.S. It indicates that relative unemployment rates of blacks compared to whites rose even as the absolute unemployment rates fell for both Alabama and the U.S. as a whole. It also shows that those counties in Alabama without a Wal-Mart store saw the worst relative deterioration in relative unemployment rates. Part of the analysis presented here explores whether this apparent effect is statistically significant, ceteris paribus.

We examine four income concepts in this paper: median total income, mean total income, mean earned income, and mean wage and salary income. All income data are for households. Median income of blacks in Alabama was 52 percent that of whites in 1980 and 52.2 percent that of whites in 1990. Median income data is less sensitive to elongation of the upper tail of the income distribution than mean income data. However, detailed data for incomes are only available for the respective means. One concern with either mean or median total income is that relative gains in black earned income may be 
TABLE 1

\begin{tabular}{lccc}
\multicolumn{4}{c}{ Ratio of Black to White Unemployment Rates, Alabama and U.S. } \\
\hline Relative unemployment Rates & Counties & 1980 & 1990 \\
\hline Alabama & 67 & 2.528 & 2.640 \\
Valid counties* & 55 & 2.387 & 2.745 \\
Valid Wal-Mart counties* & 38 & 2.250 & 2.446 \\
Valid Non-Wal-Mart counties* & 17 & 2.693 & 3.413 \\
U.S. & All & 2.306 & 2.375 \\
* Valid indicates that unemployment data were available for both 1980 and 1990. The \\
data shown are based on weighted averages of unemployment rates. \\
\hline
\end{tabular}

offset or dampened by changes in unearned income beneficial primarily to white households during the rapid growth in financial wealth in the 1980s. Tables 2A and B show the number of households with various sources of income, the mean income by type, and a profile of a typical white and black household. Earned income includes wage, salary, non-farm self-employment, and farm self-employment income. Unearned income is the remainder of the categories in Table 2A. There are some substantial differences between blacks and whites. Less than 10 percent of blacks (versus 35 percent of whites) received rent, interest, or dividend income while more than 25 percent of blacks (versus 7 percent of whites) received public assistance income in 1980. The rent, interest, and dividend gap opened further in 1990. This gives rise to the possibility that using either median or mean total household income hides the impact of Wal-Mart on black income. Mean earned income, especially wage and salary income, would be most directly affected by an improvement in the employment situation of blacks. However, a glance at Tables 2A and $2 \mathrm{~B}$ indicates that both the relative mean earned income and mean wage and salary income of blacks declined slightly relative to whites.

Table 3 makes it clear that mean wage and salary income is higher in counties that attained Wal-Marts during the 1980s than in those that did not, that counties with WalMarts gained nominal income faster than non-Wal-Mart counties, and that the relative income position of blacks deteriorated more in non-Wal-Mart counties than in Wal-Mart counties. These data suggest that further analysis would be worthwhile. With respect to relative income, our working hypothesis may be restated as: blacks fared relatively better in those counties in which a Wal-Mart opened during the 1980s because a Wal-Mart opened in those counties, ceteris paribus.

\subsection{Choosing the Explanatory Variables}

Before constructing our regression models for measuring the impact of Wal-Mart, we must establish a list of independent socio-economic and demographic variables that are likely to affect both black to white income and unemployment differentials. In this 
TABLE 2A

Alabama Income by Type: 1980

\begin{tabular}{|c|c|c|c|c|c|c|c|c|}
\hline \multirow[b]{2}{*}{ Type of Income } & \multicolumn{3}{|c|}{ Whites } & \multicolumn{3}{|c|}{ Blacks } & \multicolumn{2}{|c|}{$\begin{array}{c}\text { Black to White } \\
\text { Ratios } \\
\end{array}$} \\
\hline & $\begin{array}{l}\text { Number of } \\
\text { Households }\end{array}$ & $\begin{array}{c}\text { Mean } \\
\text { Income }\end{array}$ & $\begin{array}{c}\text { Typical } \\
\text { Family Profile } \\
\end{array}$ & $\begin{array}{l}\text { Number of } \\
\text { Households }\end{array}$ & $\begin{array}{c}\text { Mean } \\
\text { Income }\end{array}$ & $\begin{array}{c}\text { Typical } \\
\text { Family Profile } \\
\end{array}$ & $\begin{array}{c}\text { Ratio } \\
\text { of Means } \\
\end{array}$ & $\begin{array}{c}\text { Ratio } \\
\text { of Profile } \\
\end{array}$ \\
\hline Earned & 841,613 & $\$ 19,127$ & $\$ 15,485$ & 213,517 & $\$ 12,320$ & $\$ 8,902$ & 0.644 & 0.575 \\
\hline Unearned & & & 3,094 & & & 2,207 & & 0.713 \\
\hline Wage and Salary & 800,686 & 18,308 & 14,102 & 210,632 & 12,189 & 8,688 & 0.666 & 0.616 \\
\hline Non-Farm Self & & & & & & & & \\
\hline Employment & 97,256 & 12,563 & 1,175 & 8,293 & 6,614 & 186 & 0.526 & 0.158 \\
\hline Farm Self & & & & & & & & \\
\hline Employment & 43,759 & 4,948 & 208 & 2,481 & 3,308 & 28 & 0.669 & 0.133 \\
\hline $\begin{array}{l}\text { Interest, Dividends, } \\
\text { \& Rent }\end{array}$ & 355,745 & 2,672 & 914 & 20,535 & 1,052 & 73 & 0.394 & 0.080 \\
\hline Social Security Inc & 286,314 & 3,850 & 1,060 & 96,928 & 3,141 & 1,030 & 0.816 & 0.972 \\
\hline Public Assistance & 73,379 & 1,912 & 135 & 72,675 & 1,907 & 469 & 0.997 & 3.475 \\
\hline Retirement Income & & & & & & & & \\
\hline All Other & 251,488 & 4,068 & 984 & 62,900 & 2,985 & 635 & 0.734 & 0.646 \\
\hline Total & $1,039,531$ & $\$ 18,579$ & $\$ 18,579$ & 295,503 & $\$ 11,109$ & $\$ 11,109$ & 0.598 & \\
\hline
\end{tabular}


TABLE 2B

Alabama Income by Type: 1990 State Profile 1990

\begin{tabular}{|c|c|c|c|c|c|c|c|c|}
\hline \multirow[b]{2}{*}{ Type of Income } & \multicolumn{3}{|c|}{ Whites } & \multicolumn{3}{|c|}{ Blacks } & \multicolumn{2}{|c|}{ Black to White Ratios } \\
\hline & $\begin{array}{c}\text { Number of } \\
\text { Households }\end{array}$ & $\begin{array}{c}\text { Mean } \\
\text { Income }\end{array}$ & $\begin{array}{c}\text { Typical } \\
\text { Family Profile } \\
\end{array}$ & $\begin{array}{l}\text { Number of } \\
\text { Households } \\
\end{array}$ & $\begin{array}{c}\text { Mean } \\
\text { Income }\end{array}$ & $\begin{array}{c}\text { Typical } \\
\text { Family Profile } \\
\end{array}$ & $\begin{array}{c}\text { Ratio } \\
\text { of Means } \\
\end{array}$ & $\begin{array}{c}\text { Ratio } \\
\text { of Profile } \\
\end{array}$ \\
\hline Earned & 911,101 & $\$ 34,632$ & $\$ 27,262$ & 243,734 & $\$ 21,844$ & $\$ 15,901$ & 0.631 & 0.583 \\
\hline Unearned & & & 6,485 & & & 3,322 & & 0.512 \\
\hline Wage and Salary & 876,927 & 33,180 & 25,139 & 240,093 & 21,661 & 15,532 & 0.653 & 0.618 \\
\hline Non-Farm Self & & & & & & & & \\
\hline $\begin{array}{l}\text { Employment } \\
\text { Farm Self }\end{array}$ & 124,474 & 17,876 & 1,922 & 12,880 & 9,109 & 350 & 0.510 & 0.182 \\
\hline Employment & 27,071 & 8,575 & 201 & 1,466 & 4,177 & 18 & 0.487 & 0.091 \\
\hline $\begin{array}{l}\text { Interest, Dividends, } \\
\text { \& Rent }\end{array}$ & 418,078 & 6,028 & 2,177 & 24,566 & 2,070 & 152 & 0.343 & 0.070 \\
\hline Social Security Inc & 335,444 & 7,259 & 2,104 & 96,580 & 5,504 & 1,588 & 0.758 & 0.755 \\
\hline Public Assistance & 64,280 & 3,231 & 179 & 65,548 & 2,745 & 537 & 0.850 & 2.995 \\
\hline Retirement Income & 192,434 & 9,741 & 1,620 & 39,117 & 6,142 & 718 & 0.631 & 0.443 \\
\hline All Other & 122,271 & 3,829 & 405 & 37,093 & 2,954 & 327 & 0.771 & 0.809 \\
\hline Total & $1,157,406$ & $\$ 33,747$ & $\$ 33,747$ & 334,828 & $\$ 19,223$ & $\$ 19,223$ & 0.570 & \\
\hline
\end{tabular}


TABLE 3

\begin{tabular}{|c|c|c|c|c|}
\hline & \multirow{2}{*}{$\begin{array}{c}\text { Valid } \\
\text { Counties* }\end{array}$} & \multicolumn{3}{|c|}{ Mean Wage and Salary Income } \\
\hline & & White & Black & Black/White Ratio \\
\hline 1980 Wal-Mart Counties & 38 & $\overline{18,362}$ & 12,495 & 0.671 \\
\hline 1980 Non Wal-Mart Counties & 16 & 16117 & 10,855 & 0.674 \\
\hline Ratio of non-Wal-Mart to Wal-Mart & & 0.865 & 0.869 & \\
\hline 1990 Wal-Mart Counties & 39 & 34,038 & 22,144 & 0.651 \\
\hline 1980 Non-Wal-Mart Counties & 22 & 28,999 & 18,690 & 0.644 \\
\hline Ratio of non-Wal-Mart to Wal-Mart & & 0.852 & 0.844 & \\
\hline
\end{tabular}

section we discuss the chosen explanatory variables and our priors for the signs of their coefficients. The dependent and explanatory variables are listed and defined in Table 4.

We posit that each of the four income differentials is impacted by the relative ages of the two populations, relative years of education, the industrial mix of the county, and the percentage of the county that is black. Younger workers have less on-the-job training and less accumulative experience. In addition, younger workers have more frequent spells of unemployment. Furthermore, we posit that income differentials diminish with level of education completed by blacks relative to that of whites. Thus, the ratio of the percentage of the black population over 25 with a college degree to the same percentage for the white population is also used as a control variable. While income differences of whites relative to blacks tend to increase as education for both groups increases, an increase in this ratio is equivalent to an increase in educational attainment of blacks, holding that of whites constant. We expect that the ratio of black income to white income will increase with the percent of the labor force in manufacturing, decrease with the percent in retail trade, and is impacted by the percent of population in agriculture. The case of agriculture is more complex, and we have no priors on the sign of this variable. ${ }^{7}$

The variables examined with respect to relative unemployment rates are similar to that for incomes. Blacks had unemployment rates in 1980 that averaged 2.39 times the unemployment rates of whites. We again posit that part of the differences between

\footnotetext{
${ }^{7}$ Agricultural employment includes self-employed farmers, farm workers, and employment in agricultural services. Market rates of return to equally capitalized farms should be color blind. It may be the case that black farms are undercapitalized compared to white farms. The data show that farm self-employment was earned by 4.2 percent and 2.6 percent of white households in 1980 and 1990, respectively, but by only 0.8 percent and 0.4 percent of black households. White selfemployed farmers earned 150 percent and 205 percent more than self-employed black farmers in 1980 and 1990, respectively. However, it is also the case that self-employment income in agriculture is a minuscule part of the typical black household income.
} 
TABLE 4

\section{Definition of Variables}

\begin{tabular}{|c|c|}
\hline Variable Name & Description \\
\hline pagr80, pagr90 & $\begin{array}{l}\text { The percentage of the labor force employed in agriculture in } \\
1980 \text { and in } 1990\end{array}$ \\
\hline pmanu80, pmanu90 & $\begin{array}{l}\text { The percentage of the labor force in manufacturing in } 1980 \text { and } \\
1990\end{array}$ \\
\hline pretail80, pretail90 & $\begin{array}{l}\text { The percentage of the labor force in retail trade in } 1980 \text { and in } \\
1990\end{array}$ \\
\hline rmdage 80 , rmdage 90 & $\begin{array}{l}\text { The ratio of the median age of blacks to the median age of } \\
\text { whites }\end{array}$ \\
\hline rcoll80, rcoll90 & $\begin{array}{l}\text { The ratio of the percent of blacks with a college degree to the } \\
\text { percent of whites with a college degree }\end{array}$ \\
\hline rmdinc 80 , rmdinc 90 & $\begin{array}{l}\text { The ratio of median income of blacks to the median income of } \\
\text { whites }\end{array}$ \\
\hline rminc 80 , reminc 90 rearned 80 & The ratio of mean total incomes \\
\hline rearned90 & The ratio of mean earned incomes \\
\hline rwages 80 , rwages 90 & The ratio of mean wage and salary incomes \\
\hline $\begin{array}{l}\text { runrate80 } \\
\text { runrate90 }\end{array}$ & $\begin{array}{l}\text { The ratio of the black unemployment rate to the white } \\
\text { unemployment rate }\end{array}$ \\
\hline waldum & $\begin{array}{l}\text { Dummy for at least one Wal-Mart entering the market during } \\
\text { the } 1980 \mathrm{~s}\end{array}$ \\
\hline yearswith & $\begin{array}{l}\text { Years from opening of the first Wal-Mart in each county until } \\
1990\end{array}$ \\
\hline Adjacent & Dummy $=1$ for counties adjacent to central city counties \\
\hline Centralc & Dummy $=1$ for counties containing a MSA central city \\
\hline Incratio & Ratio of rmdinc 90 to rmdinc 80 \\
\hline meanration & Ratio of rminc 90 to rminc 80 \\
\hline Earninratio & Ratio of rearned90 to rearned90 \\
\hline wagesratio & Ratio of rwages 90 to rwages 80 \\
\hline Unemratio & Ratio of runrate 90 to runrate 80 \\
\hline Perblk80 & Percent of county population that is black in 1980 \\
\hline $\begin{array}{l}\text { Growhite } \\
\text { Growblk }\end{array}$ & $\begin{array}{l}\text { Percent growth of the white and black populations by county, } \\
1980 \text { to } 1990\end{array}$ \\
\hline $\begin{array}{l}\text { Ageratio } \\
\text { Collratio } \\
\text { Manuratio } \\
\text { Agratio } \\
\text { Retailratio } \\
\text { Rperblk90to80 }\end{array}$ & Ratios of the 1990 variable to the corresponding 1980 variable \\
\hline
\end{tabular}


black and white unemployment rates is accounted for by the lower educational level and the younger ages of blacks. Furthermore, the more manufacturing contributes to the local economy, the smaller should be the difference in unemployment rates for two reasons. Manufacturing is more likely to compete in a national market than is the low-skilled end of the service sector, and thus manufacturing firms are likely to pay a higher price for utility maximizing behavior than those in the low-skilled end of the service sector. Second, it is also likely that discrimination in manufacturing is more visible and thus more subject to equal opportunity law enforcement. Our final variable is the ratio of black males to black females in each county. National data indicate that the unemployment rate of black males is consistently higher than that of black females. Since we do not have separate unemployment data for males and females by race, we use the male-tofemale population ratio to partially account for this difference. A high male-to-female ratio is expected to raise a county's black-to-white unemployment rate ratio.

Using 1980 county data, we estimated simple linear models with the four measures of income ratios and our measure of the unemployment ratio as dependent variables, and the socio-economic and demographic variables as independent variables to determine whether we were, indeed, on the right track. All of the signs for the significant explanatory variables for the relative income regressions are as postulated. Simple linear relationships accounted for 42 percent to 50 percent of the variation in the income ratios. RCOLL80 has a positive and significant effect on relative incomes for all concepts except mean total income; PAGR80 and PRETAIL80 have significant negative effects for all income concepts except median income. PMANU80 is not significant for any of the income concepts. Not surprisingly, PERBLK80 is negatively associated with all of the income ratios and is the strongest explanatory variable. The results for relative unemployment rates are similar to those for income and also have the expected signs with one exception. In this equation, which explains 44 percent of the variance in county-tocounty unemployment ratios, neither PAGR80 nor PRETAIL80 is statistically significant. But RMADAGE80, PMANU80, and RCOLL80 are strongly significant. Interestingly, the male-to-female ratio is statistically significant but has an unexpected sign. ${ }^{8}$

\subsection{Testing the Impact of Wal-Mart}

Over the course of the decade of 1980s, Wal-Marts opened in 43 counties, leaving 23 counties with no Wal-Mart present at the beginning of 1990. One way to use these counties as a control group is to employ a $\{0,1\}$ dummy variable for the presence of a Wal-Mart. However, it is possible that the presence of a Wal-Mart would require some time to have an effect on black-white income or unemployment differentials. This was explored by using a variable that measures the time between the opening date of the first Wal-Mart in each county and January 1, 1990.

To explore the impact of Wal-Mart on relative income and unemployment rates, we use ratios of ratios. That is, we use the ratio of the black-white income ratio in 1990 to

\footnotetext{
${ }^{8}$ The authors would be willing to send these results to any interested reader.
} 
the black-white income ratio in 1980 as the measure of the impact of the independent variables on income. We use a similar procedure for unemployment rates. With respect to income, convergence would imply that the ratio of ratios would be greater than one and the impact of Wal-Mart would be positive. For unemployment convergence, the ratio of ratios will be less than one and the impact of Wal-Mart is expected to be negative. Similarly an increase in the ratio of college-educated blacks to college-educated whites or an increase in ratio of average ages would positively affect the income ratio and negatively affect the unemployment ratio.

Counties differ from one another in the degree to which they are urban or influenced by an adjacent urban area. To explore the possibility that Wal-Mart's effect on income might differ depending on proximity to a metropolitan area, we created two dummy variables, CENTRALC, which is one if the county contains the central city of a metropolitan area, and ADJACENT, which is one for all counties that abut a central city county. Given that there are blocks of majority black counties in south-central Alabama and blocks of nearly white counties in other parts of the state, there is the possibility of spatial autocorrelation in both the income and unemployment data. Its presence is usually an indication of a spatial transmission mechanism in the dependent variables. In the case of either relative wages or relative income, migration or commuting patterns are possible transmission mechanisms, as is education quality if black majority counties spend systematically less per student. We tested for spatial autocorrelation in the ratio of income ratios, the ratio of unemployment ratios, and the error terms for the regressions reported in Tables 4 and 5 using Moran's I. By this measure, there is no significant spatial autocorrelation in either dependent variable or in the error terms. ${ }^{9}$

No significant results were obtained for any of the four income concepts and our set of explanatory variables, with the exception of YEARSWITH, which is significant in explaining the ratio of ratios of wage and salary income equation. As a result, we report in Table 5 only the regression results for the wage and salary income. Given the Fstatistics, it appears that the independent variables had no joint impact on the relative incomes of blacks during this decade. ${ }^{10}$ In a regression in which YEARSWITH is the only explanatory variable, however, the length of time that Wal-Mart was present in a county is significantly $(\rho=.08)$ and positively related to improvement in relative wage and salary income for blacks. We expand on this result in the interpretation section.

Table 6 shows the results for the ratio of unemployment ratios. All of the significant variables have the expected sign. Both the Wal-Mart dummy and the YEARSWITH Wal-Mart variables are significant and of the correct sign. The results suggest that the

\footnotetext{
${ }^{9} \mathrm{We}$ assigned $w_{i j}=1$ if two counties were linked, zero otherwise. No links to adjoining counties in other states were included as we had no data for those counties. There are 160 potential links between Alabama counties. Of these, 63 were lost due to missing income data and 49 were lost due to missing employment data. All Z-values were less than one.

${ }^{10}$ It is important to note that when Newey-West corrections for heteroskedasticity are used, it is the significance of the t-tests that matters. The econometric literature is silent on the effect of these corrections on the F-statistic for the regression.
} 
TABLE 5

Presence and Length of Presence of Wal-Mart Impact on Black-to-White Relative Incomes Newey-West HAC Standard Errors and Covariance Based T-Statistics

\begin{tabular}{|c|c|c|c|c|}
\hline \multirow{2}{*}{$\begin{array}{l}\text { Dependent Variable } \\
\text { Observations } \\
\text { Independent Variables }\end{array}$} & \multicolumn{2}{|c|}{$\begin{array}{l}\text { WAGESRATIO } \\
47\end{array}$} & \multicolumn{2}{|c|}{$\begin{array}{c}\text { WAGESRATIO } \\
47\end{array}$} \\
\hline & Coefficient & t-Statistic & Coefficient & t-Statistic \\
\hline Constant & 0.635 & 0.975 & 0.711 & 1.010 \\
\hline AGERATIO & 0.093 & 0.204 & 0.050 & 0.101 \\
\hline COLLRATIO & -0.007 & -0.238 & -0.013 & -0.431 \\
\hline MANURATIO & 0.078 & 0.371 & 0.085 & 0.452 \\
\hline AGRATIO & -0.017 & -0.196 & -0.060 & -0.693 \\
\hline RETAILRATIO & 0.058 & 0.253 & 0.097 & 0.420 \\
\hline RBLK90TO80 & 0.087 & 0.340 & 0.047 & 0.179 \\
\hline CENTRALC & 0.010 & 0.157 & 0.005 & 0.082 \\
\hline ADJACENT & 0.074 & 1.242 & 0.071 & 1.175 \\
\hline WALDUM & 0.066 & 1.391 & --- & --- \\
\hline YEARSWITH & --- & --- & 0.011 & $1.909^{*}$ \\
\hline R-squared & 0.112 & & 0.152 & \\
\hline Adjusted R-squared & -0.105 & & -0.054 & \\
\hline S.E. of regression & 0.135 & & 0.131 & \\
\hline F-statistic & 0.516 & & 0.737 & \\
\hline Prob(F-statistic) & 0.853 & & 0.673 & \\
\hline
\end{tabular}

number of years that a Wal-Mart is present is important in reducing the unemployment rate discrepancy between blacks and whites. The urban proximity dummies were insignificant and substantially reduce the adjusted R-squares and therefore were omitted from this regression.

\section{INTERPRETATION}

The data in Tables 2A and 2B show that in the counties for which data is available, both mean wage and salary income and mean earned income of blacks relative to whites decreased slightly (0.666 to 0.653 and 0.644 to 0.631 , respectively) from 1980 to 1990 . The relative decline of mean total incomes of blacks is somewhat more substantial (0.598 to 0.570 ) than the decline in mean wage and salary income because of the comparatively large decline in the relative amount of unearned income going to blacks. The relationship of income changes and the Wal-Mart-non-Wal-Mart distinction is even more complex. This may be due, in part, to sampling artifacts in 1980, as the U.S. Census was able to successfully sample seven more counties in 1990. Nonetheless, for the 51 counties for which there are consistent total income measures in both 1980 and 1990, the decline in 
TABLE 6

Presence of Wal-Mart and the Ratio of 1990 to 1980 Relative Unemployment Rates Newey-West HAC Standard Errors and Covariance Based t-Statistics

\begin{tabular}{|c|c|c|c|c|}
\hline \multirow{2}{*}{$\begin{array}{l}\text { Dependent Variable } \\
\text { Observations } \\
\text { Independent Variables }\end{array}$} & \multicolumn{2}{|c|}{$\begin{array}{l}\text { UNEMRATIO } \\
55\end{array}$} & \multicolumn{2}{|c|}{$\begin{array}{l}\text { UNEMRATIO } \\
55\end{array}$} \\
\hline & Coefficient & t-Statistic & Coefficient & t-Statistic \\
\hline Constant & 4.454 & $3.057^{* * *}$ & 4.074 & $2.809^{* * *}$ \\
\hline COLLRATIO & -0.167 & $-1.877^{*}$ & -0.165 & $-1.817^{*}$ \\
\hline AGERATIO & -3.779 & $-3.562^{* * *}$ & -3.289 & $-2.022^{* *}$ \\
\hline AGRATIO & -0.295 & -1.227 & -0.189 & -0.769 \\
\hline MANURATIO & 0.398 & 0.621 & 0.599 & 0.955 \\
\hline RETAILRATIO & 0.592 & 1.154 & 0.556 & 1.067 \\
\hline RBERBLK90TO80 & 0.316 & 0.663 & 0.235 & 0.492 \\
\hline WALDUM & -0.260 & $-2.042^{* *}$ & -- & --- \\
\hline YEARSWITH & --- & --- & -0.026 & $-1.677^{*}$ \\
\hline R-squared & 0.313 & & 0.294 & \\
\hline Adjusted R-squared & 0.211 & & 0.189 & \\
\hline S.E. of regression & 0.369 & & 0.374 & \\
\hline F-statistic & 3.061 & & 2.801 & \\
\hline Prob(F-statistic) & 0.010 & & 0.016 & \\
\hline
\end{tabular}

relative total incomes was less in Wal-Mart counties (0.022) than in non-Wal-Mart counties (0.041). Thus, the decline in relative incomes of blacks may be due to changes in other demographic variables that the presence of Wal-Mart partially mitigated.

With respect to wage and salary income, the average over all counties for the ratio of ratios is 0.978 , reflecting the fact that for the state, the relative wage and salary income of blacks fell by a little over 2 percent during the 1980s. A regression with only the WalMart dummy present shows that Wal-Mart's presence is associated with an increase in relative wage and salary incomes of blacks at the 11 percent level of significance $(\rho=0.1066)$. Furthermore, improvement in the relative wage and salary income of blacks is also associated with the number of years Wal-Mart is present (YEARSWITH) at the 10 percent level $(\rho=0.0694)$. These regressions are shown here with Newey-West HAC standard errors shown in parentheses. While the effects are relatively small, they suggest that Wal-Mart has a positive effect on the relative wage earnings of blacks, which

$$
\begin{aligned}
& \text { WAGESRATIO }=0.9790+0.0521 \text { WALDUM, } \quad \mathrm{R}^{2}=0.0379 \\
& (0.0333) \quad(0.0313) \\
& \text { WAGESRATIO }=0.9784+0.00785 \text { YEARSWITH, } \mathrm{R}^{2}=0.0584 \\
& (0.0288) \quad(0.0042)
\end{aligned}
$$


accumulates over time. Equation (1) suggests that counties that acquired a Wal-Mart in the 1980 s saw a 5.2 percent increase in the relative income of blacks compared to nonWal-Mart counties. Equation (2) suggests that it takes a little under three years for the presence of a Wal-Mart to move the ratio of wage ratios above one. We added both of the urban proximity variables to these equations, and again they improved the significance of both of the Wal-Mart variables and the overall regression. ADJACENT is almost significant at the 15 percent level and is positive for both regressions. It appears that counties adjacent to central cities saw slightly greater improvement in black-to-white income ratios. This might be the impact of higher income blacks commuting to the central city. We explore commuting patterns more fully below. We did not find significant results for any other income concept, but this was not unexpected for reasons outlined earlier. It is clear from the low $\mathrm{R}^{2} \mathrm{~s}$ that other variables are important and may overwhelm the statistical impact of Wal-Mart shown here and in Table 5.

To this point our focus has been on relative incomes. It is also possible to examine whether counties with Wal-Marts performed differently with regard to absolute changes in black incomes. To test this possibility, we examined the absolute change in real income (created using the Personal Consumption Expenditure Price Index). For the 53 counties with valid income measures for both 1980 and 1990, the average increase in real absolute wage and salary income for blacks was 17.8 percent. There is substantial variance in individual county outcomes, with changes ranging from a gain of 67.6 percent (St. Clair County) to a loss of 22.3 percent (Franklin County). To test whether the variance in county income changes had any relationship to the presence of a Wal-Mart, we controlled for several socioeconomic variables. The average age of the black population increased by four years over this decade. The percentage of blacks with college education increased by 39 percent. Again there was a great deal of variance, with Jackson County seeing more than a 400 percent gain and DeKalb county seeing a 62.5 percent decrease. We tested the hypothesis that ratio of black wage income in 1990 to that in 1980 would be sensitive to the relative increase in average age, the relative change in the percent of blacks with college education, and the presence of Wal-Mart. The results, shown in Table 7, indicate that none of these variables explain any part of the county-to-county variation in changes in real income during the $1980 \mathrm{~s}$.

Recall that Table 1 shows the ratios of unemployment rates for all counties, WalMart counties, and non-Wal-Mart counties for 1980 and 1990. As indicated in that table, the relative unemployment rate of blacks increased in all counties, but by substantially less in counties with a Wal-Mart than in those counties without a Wal-Mart. The results shown in Table 6 seem to verify that the presence of one or more Wal-Marts was mitigating the influence of other socioeconomic factors on the relative unemployment rates of blacks. In the counties where Wal-Mart is present, blacks fare better in jobs than in those counties without a Wal-Mart.

Given the above discussion, our results seem somewhat contradictory. While the presence and the years with a Wal-Mart have a significant effect on unemployment differentials, they only have a significant impact on one concept of income (wages and 
TABLE 7

\begin{tabular}{|c|c|c|c|}
\hline \multicolumn{4}{|c|}{ Ratio of Absolute Changes in Black Income } \\
\hline $\begin{array}{l}\text { Dependent Variable } \\
\text { Observations }\end{array}$ & $\begin{array}{c}\text { RBLW90TO80 } \\
51 \\
\end{array}$ & & \\
\hline$\underline{\text { Dependent Variables }}$ & Coefficient & t-Statistic & Prob. \\
\hline $\mathrm{C}$ & 0.800798 & 1.611500 & 0.1138 \\
\hline RCOLLBKS & 0.005539 & 0.199587 & 0.8427 \\
\hline RAGEBLK & 0.293524 & 0.709338 & 0.4816 \\
\hline WALDUM & 0.033502 & 0.733696 & 0.4668 \\
\hline R-squared & 0.020069 & F-Statistic & 0.320860 \\
\hline Adjusted R-squared & -0.042479 & Prob (F-statistic) & 0.810231 \\
\hline S.E. of regression & 0.148769 & & \\
\hline
\end{tabular}

salaries) and this effect is quite limited. Three possible explanations for this difference come to mind. ${ }^{11}$ First, neoclassical economics suggests that to the degree that rational individuals know that the existence of a Wal-Mart might lead to better opportunities, lowskilled workers would migrate to those areas where a Wal-Mart exists. This would lower the labor force in non-Wal-Mart counties and raise the labor force in Wal-Mart counties. This migration could, theoretically, both increase mean wage and salary income and decrease unemployment rates in non-Wal-Mart counties while reducing average incomes and increasing unemployment rates in Wal-Mart counties. The actual outcome depends on the employment status of migrants at their point of origin. Depending on the relative impacts of these effects on the labor markets of the two types of counties, it is certainly empirically possible that the unemployment differential could lessen without an accompanying decrease in the income differential.

The possibility is quite intriguing that after any migration has occurred, there are substantial changes in unemployment differentials but not income differentials. With respect to employment, our result, as stated above, is consistent with those of Bartik (1991, 1993). There are three sources of employees for newly created jobs: the currently unemployed, new entrants via an increase in the participation rate of current residents, and nonresidents who either migrate or commute to the new jobs from outside the local area. If Bartik's results apply to our case, and if the workers in the locale of a new WalMart are just as qualified for these new jobs as workers in other counties, approximately 25 percent of the new jobs would go to local residents, with 8 percent of these jobs going to those who were previously unemployed and 17 percent going to local residents who previously did not participate in the labor force. While the percentage of jobs going to local residents is relative low, the expansion of jobs is relatively large for the currently unemployed and low-skilled workers in Bartik's model. We seem to be verifying this for Alabama.

${ }^{11} \mathrm{We}$, of course, do not believe that the following explanations are all-encompassing. 
On the other hand, with respect to income differentials, our results seem to agree with Blanchard and Katz (1992), who suggest that in the long run, migration eliminates almost all gains in unemployment rates and incomes from a demand increase in the host county. Since Wal-Mart provides an employer at the low end of the wage and skill scale, these newly created jobs would be expected to lower the unemployment rate, ceteris paribus. However, since these newly created jobs are not very high paying, it is possible that they would not change income differentials very much. Thus it is possible that Wal-Mart, by providing such jobs, creates results that are atypical.

A second explanation follows Hirsch's (1978) hypothesis of "occupational crowding." It is possible that the wages of whites may have been depressed in Alabama in the 1970s because the concentration of non-whites combined with the structure of occupations and industries that focused on low-skill workers. If this was the case, then, according to Hirsch, occupational crowding would have occurred. If Wal-Mart increased demand for low-skilled workers sufficiently to overcome such occupational crowding, white low-skilled workers would see an increase in wages that matched or exceeded the increase in wages of low-skilled black workers. This would leave no improvement in the relative earnings of blacks, even though the relative unemployment rate of blacks would improve.

Third, it must be noted that employment and income data are garnered from where people live and not where they work. Therefore, if there is any commuting, some of the income and employment benefits accrue to people who actually don't live in the county where the Wal-Mart is established. By dividing our data into Wal-Mart and non-WalMart counties, we are potentially underestimating Wal-Mart's effect on income and unemployment differentials. For example, suppose blacks get all the new jobs at a WalMart in county X. If all these new employees lived in county $\mathrm{Y}$, then relative to county $\mathrm{X}$, it would appear that Wal-Mart hurt unemployment differentials with respect to blacks when this isn't the case. This would suggest that an examination of commuting data might be useful.

We did examine county-to-county commuting patterns, which are shown in Table 8. Commuting increased substantially in the 1980s as service sector employment followed the earlier dispersal pattern of manufacturing employment and the real cost of gasoline declined. As the table indicates, commuting increased more for non-Wal-Mart counties than for those counties that obtained Wal-Marts. However, when commuting patterns are controlled for the effects of counties being central city counties or counties adjacent to central city counties, Wal-Mart's presence does not explain a significant amount of the remaining variance. It is positively but not quite statistically significantly associated with out-commuting and bears no relationship to in-commuting. ${ }^{12}$

12 There is evidence that rural-to-urban commuting does reduce wage disparities (Hazans, 2004), but the data requirements were beyond the scope of this study. 
TABLE 8

Change in Commuting Patterns in Alabama, 1980 -1990

\begin{tabular}{llllllll}
\hline & \multicolumn{3}{c}{ Wal-Mart Counties } & & Non-Wal-Mart Counties \\
\cline { 2 - 3 } Type of Commute & 1980 & 1990 & Change & & 1980 & 1990 & Change \\
\hline $\begin{array}{l}\text { Percent of county workforce } \\
\text { commuting into county of } \\
\text { employment }\end{array}$ & 15.9 & 19.3 & 3.37 & & 18.0 & 22.8 & 4.77 \\
$\begin{array}{l}\text { Percent of employed residents } \\
\text { commuting out of county of } \\
\text { residence }\end{array}$ & 16.6 & 19.7 & 3.04 & & 30.2 & 34.1 & 3.95 \\
\hline Source: U.S. Census, County to County Worker Flow Files & & & & & & \\
\hline
\end{tabular}

Finally, another possible caveat concerning our results must be addressed. While we found evidence that Wal-Mart has a substantial impact on unemployment rate differentials, this impact could be deceiving if Wal-Mart generally placed their stores in counties that had a trend of narrowing unemployment rate differentials. Thus, it might be worthwhile to examine Wal-Mart's location decisions. Wal-Mart does not release explicit statistical information about how it chooses locations. However, given that we are only interested in the counties chosen (not the particular location in the county), we can shed some light on the choice of particular counties. Using a $\{0,1\}$ dummy (WALDUM) to indicate the absence or presence of Wal-Mart, we performed a probit analysis of WalMart's choice of counties. The independent variables were the rate of population growth during the decade of the 1970s (POPGRO70S), the growth of per capita income in the 1970s (PCIGRO70S), the percentage of employment in the retail sector as of 1980 (PRETAIL80), the male-to-female ratio (MFRATIO80), and the percentage of the local population that was black in 1980 (PERBLK80). The explanatory variables are data that would have been readily available to Wal-Mart at the beginning of the 1980s. The results are shown in Table 9. All of the variables except the ratio of males to females were significant at the 10 percent level or better.

The composite picture that emerges from this probit analysis is that Wal-Mart was seeking counties in which retail trade was under-represented in the local employment mix, incomes were rising relatively slowly, population was growing relatively rapidly, and the racial composition was relatively whiter than the average Alabama county. It appears, then, that Wal-Mart, by establishing a discount retailer that employed a substantial number of low-skilled workers, was filling a niche that was not adequately served in these counties. That is, in the counties that Wal-Mart chose, there would be little displacement effect on retail workers. If this is the case, then there is some reason to believe that the income and employment improvements that occurred in the Wal-Mart counties would not have occurred in the same magnitude in the absence of Wal-Mart. ${ }^{13}$

\footnotetext{
${ }^{13}$ Of course, this assumes that had Wal-Mart not come to these counties, other discount retailers wouldn't have entered these counties instead.
} 
TABLE 9

Binary Probit Analysis of Probability of Wal-Mart Locating in a County

\begin{tabular}{ccccc}
\hline \multicolumn{1}{c}{ Variable } & Coefficient & Std. Error & z-Statistic & Prob. \\
\hline Constant & 8.146611 & 6.347102 & 1.283516 & 0.1993 \\
PRETAIL80 & -5.413865 & 2.948385 & -1.836214 & 0.0663 \\
POPGRO70S & 5.675169 & 2.787522 & 2.035897 & 0.0418 \\
MFRATIO80 & -0.041951 & 0.059718 & -0.702487 & 0.4824 \\
PERBLK80 & -0.023645 & 0.014290 & -1.654705 & 0.0980 \\
PCIGRO70S & -1.963208 & 0.955841 & -2.053906 & 0.0400 \\
\hline Mean dependent var & 0.629032 & S.D. dependent var & 0.487007 \\
S.E. of regression & 0.399168 & Sum squared resid & 8.922770 \\
Log likelihood & -28.11676 & Avg. log likelihood & -0.453496 \\
LR statistic (5 df) & 25.54061 & McFadden R-squared & 0.312331 \\
Probability(LR stat) & 0.000110 & & \\
\hline Obs with Dep=0 & 23 & & \\
Obs with Dep=1 & 39 & & \\
\hline
\end{tabular}

\section{CONCLUSIONS}

This paper examines the impact of a Wal-Mart on the income and unemployment differentials in Alabama counties during the decade of the 1980s. It differs from previous work in that it focuses on the impact of one large firm that hires workers at the low end of the skills distribution. Thus, one might expect that human capital considerations would not be relevant in terms of excluding workers from obtaining these new job offerings. Furthermore, since most of the migration literature generally examines increases in labor demand over the full spectrum of skills, it is thought that such an investigation might yield atypical results. In fact, this is somewhat the case since our findings are mixed. Our empirical work indicates that the existence of a Wal-Mart and the length of time in which a Wal-Mart is present make a significant impact on the relative unemployment rate of blacks in Alabama counties. It also appears that Wal-Mart has a significant but weak effect on the relative income of blacks. Our results support the hypothesis that the longrun results could be cumulative. The impact on unemployment rates suggests that local residents obtained jobs they would not otherwise have had. These jobs provide job skills. While the opening of a Wal-Mart is a one-time event, those receiving jobs are permanently better off because of these increased skills. Thus, one direction for future research would be to examine the long-run effects of Wal-Mart (or any other big box retailer) on those hired after an opening by following a cohort of those employees for a number of years. 
There are four important reservations with this analysis. First, because of the possibility of laborers from non-Wal-Mart counties commuting to Wal-Mart counties, it is possible that our results understate the impact of Wal-Mart on both income and unemployment differentials. That is, some of the benefits might be accruing in the workers' place of residence rather than their place of work. Second, from our data set it is impossible to determine the long-run effects on retail activities that are complements to and/or substitutes of Wal-Mart. We have only examined the impact of Wal-Mart over a ten-year period. Since most Wal-Marts are longer lasting, it is quite possible that we are examining this issue too early. Third, the results obtained are only relevant for Alabama during this time period. It is likely that the labor markets, the culture, and the legal environment facing Wal-Mart are quite different in other states and might even be different for Alabama over different periods of time. These results represent only a small part of the impact of a Wal-Mart upon the inhabitants of a given economic area. Each of these reservations provides an avenue for further research. Finally, the results of this study would not be, for the most part, very useful for those who argue either for or against the establishment of a Wal-Mart in any given community.

\section{REFERENCES}

Alchian, A. and R. Kessel, 1962. "Competition, Monopoly, and the Pursuit of Money," in H.G. Lewis (ed.), Aspects of Labor Economics (1), 157-175. Princeton University Press: Princeton.

Bartik, T.J., 1991. Who Benefits from State and Local Economic Development Policies? W.E. Upjohn Institute for Employment Research: Kalamazoo, MI. , 1993. "Who Benefits from Local Job Growth: Migrants or the Original Residents?" Regional Studies 27(4), 297-311.

Becker, G.S., 1957. The Economics of Discrimination. University of Chicago Press: Chicago.

Berik, G., Y. van der Meulen Rodgers, and J. Zveglich, Jr., 2002. "International Trade and Wage Discrimination: Evidence from East Asia," Working Paper.

Blanchard, O.J. and L.F. Katz, 1992. "Regional Evolutions," Brooking Papers on Economic Activity (1), 1-76.

Bound, J. and H.J. Holzer, 2000. "Demand Shifts, Population Adjustments, and Labor Market Outcomes During the 1980s," Journal of Labor Economics 18(1), 20-54.

Cain, G.G., 1986. "The Economic Analysis of Labor Market Discrimination: A Survey," in O. Ashenfelter and R. Layard (eds.), Handbook of Labor Economics. Elsevier.

Hazans, M., 2004. "Does Commuting Reduce Wage Disparities?" Growth and Change 35(3), 360-390.

Hazarika, G. and R. Otero, 2002. "Foreign Trade and the Gender Earnings Differentials in Urban Mexico," United Nations University Working Paper.

Hellerstein, J.K., D. Neumark, and K.R. Troske, 2002. "Market Forces and Sex Discrimination," Journal of Human Resources 37, 353-380.

Heywood, J.S., 1987. "Wage Discrimination and Market Structure," Journal of Post Keynesian Economics 9, 617-628. 
Hirsch, B.T., 1978. "Earnings Inequality Across Labor Markets: A Test of the Human Capital Model," Southern Economic Journal 45(1), 32-45.

Holzer, H.J., 1991. "Employment, Unemployment and Demand Shifts in Local Labor Markets," The Review of Economics and Statistics 73(1), 25-32.

Johnson, R., 1978. "Racial Wage Discrimination and Industrial Structure," Bell Journal of Economics 9, 70-81.

Jones, J.C.H. and W.D. Walsh, 1991. "Product Market Imperfections, Job Content Differences, and Gender Employment Discrimination at the Management Level: Some Evidence from the Canadian Manufacturing Sector in 1971 and 1981," Canadian Journal of Economics 24, 844-858.

Kahn, L.M., 1991. "Customer Discrimination and Affirmative Action," Economic Inquiry 29, 555-571.

Medoff, M.H., 1980. "On the Relationship between Discrimination and Market Structure: Comment," Southern Economic Journal 46, 1227-1233.

Stone, K.E., 1995. "Impact of Wal-Mart Stores and other Mass Merchandisers in Iowa," 1983-1993 Economic Development Review (Spring).

U.S. Bureau of the Census, 1982. 1980 Census of Population, General Population Characteristics - United States. Government Printing Office: Washington, D.C. , 1982. 1980 Census of Population, General Population Characteristics Alabama. Government Printing Office: Washington, D.C. , 1992. 1990 Census of Population, General Population Characteristics - United States. Government Printing Office: Washington, D.C. , 1992. 1990 Census of Population, General Population Characteristics - Alabama, Government Printing Office: Washington, D.C.

U.S. Bureau of Economic Analysis, State and Local Personal Income, bea.doc.gov/ bea/regional/statelocal.htm

Welles, E.O., 1993. "When Wal-Mart Comes to Town," INC (July), 78.

Yencer, R., 2004. "New Wal-Mart Could Attract More Development," Muncie Star Press, July 21. 